aorta from the pericardial and bronchial arteries, with sclerosis or with more acutely developing obstruction from other causes, the compensatory circulation may prove inadequate or may not be promptly enough e-tablished to prevent either angina pectoris with death, or death so unexpectedly that there is no opportunity to determine whether symptoms of angina did or did not occur.

[NotE.-This and the paper by Dr. Ingals which precedes it are part of a symposium on angina pectoris read before the Institute of Medicine of Chicago. Abstracts of the remaining papers appear in the society proceedings in this issue of THE Jolrnal.-ED.]

\section{ARE DIPHTHEROIDS A FACTOR IN FEMALE STERILITY?}

T. C. STELLWAGEN, JR., M.D.

Assistant Professor of Cienito-Lrinary Surgery, Jefferson Medical College AND

P. S. PELOUZE, M.D.

Assistant Genito-Urinary Surgeon, Genito-Urinary Dispensary, University of Pennsylvauia Hospital PHILADELPHIA

The problem of sterility is of great importance to the human race. This is especially true at the present time when the flower of manhood and womanhood is being destroyed or maimed by war. We believe that the question of sterility does not receive sufficient study from investigators. With the dawn of peace will come the problem of the rehabilitation of mankind, and we feel that any procedure that offers assistance to humanity should be discussed. On matters of such magnitude as generation, we believe we shall be pardoned if we submit a single rather striking case for consideration. We aim to place before the profession a clinicolaboratory experience, hoping thereby to induce investigators of greater ability to study along this line. Valuable work has been done on the bacterial flora of the female genitalia. Little, if any, appears to have been done to ascertain the possible effects of such flora on procreation.

It is with the foregoing ideas that we report this case, presenting apparently important phases.

In the fall of 1916, Dr. X, a dentist, presented himself for study as to the cause of an anterior urethral discharge. In the history he stated that he had been married seven years, during which period he had never had any urethral discharge, nor had there been any extramarital exposure.

A study of his discharge showed it to be very largely composed of pus cells and epithelial elements. The cnly bacterium present was of the Hoffmann type of the pseudodiphtheria bacillus. This was obtained in pure culture from the anterior discharge and also from the prostatic secretion. $\mathrm{He}$ was given the usual routine local treatment for such condilions. He improved and the anterior discharge became scanty and at times disappeared. The prostatic secretion, however, still presented numerous leukocytes and organisms. The condition of the prostatic secretion and its tendency to remain in statu quo led us to reinforce our local treatment by an autogenous vaccine. Under the added impulse of vaccine therapy, the prostatic secretion became normal. At the time of making the vaccine, we deemed it wise to study the bacterial flora of the wife's genital tract with a view to determining the source of his infection and thereby obviating the possibility of future attacks. This study particularly appealed to us because of the fact that, some time previous, she had been under the care of an eminent gynecologist for a year and a half, for the purpose of correcting an apparent sterility. During this period, she had been given intravaginal medication, dilatation and curettage, and had undergone an abdominal operation for the correction of a malposed uterus. These procedures, however, failed to bring about conception, though the husband's seminal fluid contained countless numbers of very motile spermatozoa.

Our study showed that there was a complete absence of vaginal discharge. Cultures were taken from the wife's genital tract. Those from the vaginal vault presented the usual flora, with a preponderance of diphtheroids.

The cultures from the cervical canal proved to be purely diphtheroids. From a five-day growth of these bacilli, it was possible to demonstrate almost all the Westbrook types of the diphtheria bacillus, with many striking metachromatic forms. Separate autogenous vaccines were made and used on the husband and wife. Both patients canvalesced promptly with a virtual disappearance of the diphtheroids.

About three months after their dismissal, the husband returned for examination and was found free from his former infection. He was gratified to relate that he thought his wife was two months pregnant and wished us to refer him to an obstetrician for confirmation of the surmise. This was done and a positive report returned. Nov. 20, 1917, she gave birth to a healthy girl baby.

We have since had an opportunity to study bacteriologically two cases of female sterility. In one of them a pure culture of diphtheroids was obtained from the cervical canal. In the other, studied for Dr. Alexander Randall, there was a mixed culture in which diphtheroids predominated. These patients are now under treatment with antogenous vaccines in distant cities, but it is as yet too early to make a further report on their progress. We know that we have proved nothing by our meager experience, but we feel that it may encourage further study.

1831 Chestnut Street.

\section{THE FORMATION AND COMPOSITION OF THE CEREBROSPINAL FLUID}
A SIMPLE METHOD OF DETECTING ACIDOSIS AND DETERMINING HYDROGEN ION CONCENTRATION *

J. F. MCCLENDON, Ph.D. MINNEAPOLIS

THE CEREBROSPINAL FLUID

The view has been repeatedly expressed that the spinal fluid is a secretion and its composition more or less independent of the composition of the blood, but the experiments described in this paper do not favor this view. The spinal fluid is not an ordinary filtrate, such as lymph, since it is almost free from proteins, in health. It may be, however, an ultrafiltrate. Bechhold impregnated filters with colloids so that they became impermeable to proteins, and he called the apparatus an ultrafilter since it filtered out ultramicroscopic colloid particles. It seemed advisable to compare the ultrafiltrate of blood plasma with spinal fluid. The apparatus was prepared as follows: An alundum extraction shell of the finest grade was heated in a blast lamp to remove all organic matter and washed in distilled water several days to remove soluble substances. It was dried, and a perforated rubber stopper was inserted in the open end. The shell and part of the rubber stopper were coated with a solution of collodion and rotated until the smell of ether was faint, and then placed in distilled water until needed. The ultrafilter thus formed was drained and immersed

* From the Physiological Laboratory of the University of Minnesota Medical School. 